\title{
Resilience of a Building to Future Climate Conditions in Three European Cities
}

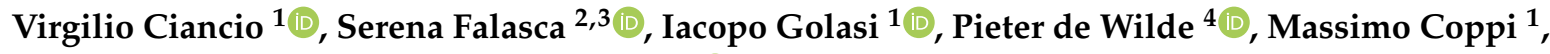 \\ Livio de Santoli ${ }^{1}$ and Ferdinando Salata ${ }^{1, *(D)}$ \\ 1 Department of Astronautical, Electrical and Energy Engineering-Applied Physics Area, University of Rome \\ "Sapienza", Via Eudossiana, 18-00184 Rome, Italy; virgilio.ciancio@uniroma1.it (V.C.); \\ iacopo.golasi@uniroma1.it (I.G.); massimo.coppi@uniroma1.it (M.C.); livio.desantoli@uniroma1.it (L.d.S.) \\ Department of Pure and Applied Sciences, University of Urbino "Carlo Bo", 61029 Urbino, Italy; \\ serena.falasca@uniurb.it \\ 3 Center of Excellence in Telesensing of Environment and Model Prediction of Severe Events (CETEMPS), \\ University of L'Aquila, 67100 Coppito-L'Aquila, Italy \\ 4 School of Art, Design and Architecture, University of Plymouth, PL4 8AA Plymouth, UK; \\ pieter.dewilde@plymouth.ac.uk \\ * Correspondence: ferdinando.salata@uniroma1.it; Tel.: +39-0648545402
}

Received: 5 November 2019; Accepted: 26 November 2019; Published: 27 November 2019

\begin{abstract}
Building energy need simulations are usually performed using input files that contain information about the averaged weather data based on historical patterns. Therefore, the simulations performed are not able to provide information about possible future scenarios due to climate change. In this work, future trends of building energy demands due to the climate change across Europe were studied by comparing three time steps (present, 2050, and -2080) in three different European cities, characterized by different Köppen-Geiger climatic classes. A residential building with modern architectural features was taken into consideration for the simulations. Future climate conditions were reached by applying the effects of climate changes to current hourly meteorological data though the climate change tool world weather file generator (CCWorldWeatherGen) tool, according to the guidelines established by the Intergovernmental Panel on Climate Change. In order to examine the resilience of the building, the simulations carried out were compared with respect to: peak power, median values of the power, and energy consumed by heating and cooling system. The observed trend shows a general reduction in the energy needs for heating $(-46 \%$ for Aberdeen, $-80 \%$ for Palermo, $-36 \%$ for Prague in 2080 compared to the present) and increase (occurrence for Aberdeen) in cooling requirements. These results imply a revaluation of system size.
\end{abstract}

Keywords: climate change; future trends; energy needs; residential sector; buildings resilience; EnergyPlus

\section{Introduction}

Over the next several decades, a primary challenge for countries all over the world will be how to reduce the demand of fossil fuels. Energy demands in developed countries affect $60 \%$ of the global electricity consumed in the residential and commercial sector. The energy used in buildings is usually $20 \%-40 \%$ of the total energy consumed from every single country, with a global average of $30 \%$ [1]. The most influential part of this type of energy consumptions is given by heating systems during cold months and cooling systems during warm months [2]. Future predictions reveal an increase in the global energy demand due to the prosperity of emerging countries (characterized by a developing economy and growing population). However, the constantly growing eco-friendly attitude adopted by 
people living in industrialized countries has caused an optimization process of energy consumptions in the residential sector [3-5].

Such situation will lead to a less accentuated growth rate of energy consumption than in the past and a decreasing use of non-renewable energy resources [6]. Over the past 20 years, there has been considerable research $[7,8]$ done to optimize building envelopes $[9,10]$ and their systems [11,12]. The technological repercussions of these researches combined with national and international regulations that impose the enhancement of energy efficiency on buildings (both existing and new) started an eco-friendly process that reduced energy consumption in the residential sector. At the end of the last century, such objective processes seemed impossible to achieve due to the fragmented situation in the real estate sector [13].

In this scenario it must be specified that the estimated energy requirement of air-conditioning systems in residential buildings during summer and winter takes into consideration the historical climate conditions of different geographical areas, which introduces important approximations [14]. It is known that the global climate is being affected by a warming process [15] caused by the greenhouse effect, which in turn is caused by anthropic activities [16]. Global climate change affects climate on a regional scale, but it also impacts local weather conditions that then have consequences on energy consumption in buildings. In order to perform precise estimations of these demands, it is important to carry out energy simulations of buildings with hourly time resolution as a function of weather data [17]. Over the past few years, the scientific community has tried to model future scenarios on regional scales in order to reveal reliable hourly data for meteorological quantities that affect energy performances in buildings [18-20]. In these studies, climate files for different geographical areas were developed. Shen examined how climate change will impact the United States [21]; Sanders and Phillipson examined how it would impact the United Kingdom [22]; Camilleri et al. carried out a case study set in New Zealand [23]; Li et al. examined the same issue in Tianjin (China) [24]; Dirks et al. focused on buildings located in the area of the Eastern Interconnection (US) [25]; Invidiata and Ghisi carried out similar studies in Brazil [26]; and Chan conducted research in Hong Kong [27]. It can be noticed that this topic is now one of main focuses of the international scientific community.

Examining the effects of future climate changes on local weather conditions is important as it creates annual weather data that simulates a building's energy behavior via software capable of predicting energy consumption.

In a previous study [20], the connection between a building's spatial location and its energy needs was investigated. In the present study, the focus shifts to the influence of the evolution of time and therefore climatic variations due to climate change. Moreover, the aim is to investigate the resilience of climate change on residential buildings in three different European cities. The cities were selected based on their geographical location (northern, middle, and southern Europe) and are characterized by different kinds of climate: Aberdeen (UK, characterized by a north Atlantic climate), Palermo (Italy, characterized by a Mediterranean climate), and Prague (Czech Republic, characterized by a continental climate). To achieve this goal, three time slices in each city were considered: the present, 2050, and 2080. For each time slice, a dynamic energy simulation was made for the same standard building using the software EnergyPlus (Section 2).

Recent studies have investigated the effect of climate change on the energy consumption of residential, commercial, and office buildings (e.g., Kalvelage et al. [28] and Shen [21] in the US; Invidiata and Ghisi [26] in South America; Jylhä et al. [29], Barbosa et al. [30], and Nik and Sasic Kalagasidis [31] in Europe; Wan et al [32] in China; Wang et al. [33] in Australia; Ouedraogo et al. in Africa [34]). The articles by Kalvalage et al. and Shen used EnergyPlus with a future weather file for US cities that belong to different climatic zones for commercial buildings and office/residential buildings. They agree on the tendency to a decrease the energy demand for heating and increase the energy demand for cooling. Further, they highlight two different consequences of climate change: the increased influence of air humidity indoors [28] and the narrowing of the energy gap between cold and hot climates in the US [21]. Invidiata and Ghisi [26] used the same methodology of this work (EnergyPlus software 
and CCWorldWeather tool for developing future weather data) on three cities in Brazil, showing that the annual energy requirements will increase up to $185 \%$ in 2080 and that a reduction of $50 \%$ in the future energy consumption could be achieved through passive design strategies. According to the results of the dynamic building energy simulations by Jylhä et al. [29], even in a northern European country such as Finland, the annual energy bill for heating will decrease by $20 \%-40 \%$ by 2100 , while the energy needs for cooling will increase by $40 \%-80 \%$. Ouedraogo et al. [34] estimated that due to climate change, indoor comfort in Burkina Faso public buildings will call for an increase of $99 \%$ for the period 2060-2079 compared to current energy consumption. They also showed the future key role of the shadowing devices in reducing the cooling load.

Wan et al. [32] calculated the carbon emissions that correspond with projected future levels of energy consumption in four Chinese climatic areas under two emissions scenarios. Moreover, Wang et al. [33] considered five regional climates in Australia under three different carbon emissions scenarios. Nik and Sasic Kalagasidis [31] considered three emissions scenarios and showed that for the warmest scenario, the cooling demand will be very low in Stockholm.

The novel contribution of this research consists in analyzing the role of climate change in geographical areas characterized by different types of climate. In fact, the simulation of the same building, if positioned in three different European cities, makes it possible to focus on the role of climate change in relation to the current climate, pointing out the resilience to climate change on buildings in different geographical areas.

\section{Materials and Methods}

\subsection{Study Cities}

In this work, three European cities were considered: Aberdeen (latitude 56.4 $4^{\circ}$ ), Prague (latitude $50.0^{\circ}$ ), and Palermo (latitude $38.0^{\circ}$ ). They are located in northern, central, and southern Europe, respectively. Thus, these cities present different climate features even though they are all European cities. According to the Köppen-Geiger classification [35,36], Aberdeen is $\mathrm{Cfb}(\mathrm{C}=$ mid-latitude temperate, $\mathrm{f}=$ wet, $\mathrm{b}=$ with hot summer), Prague is $\mathrm{Dfb}(\mathrm{D}=$ mid-latitude cold, $\mathrm{f}=$ wet, $\mathrm{b}=$ with hot summer), and Palermo is Csa ( $\mathrm{C}=$ temperate mid-latitude, $\mathrm{s}=$ dry in the summer, $\mathrm{a}=$ with very hot summer) (Figure 1).

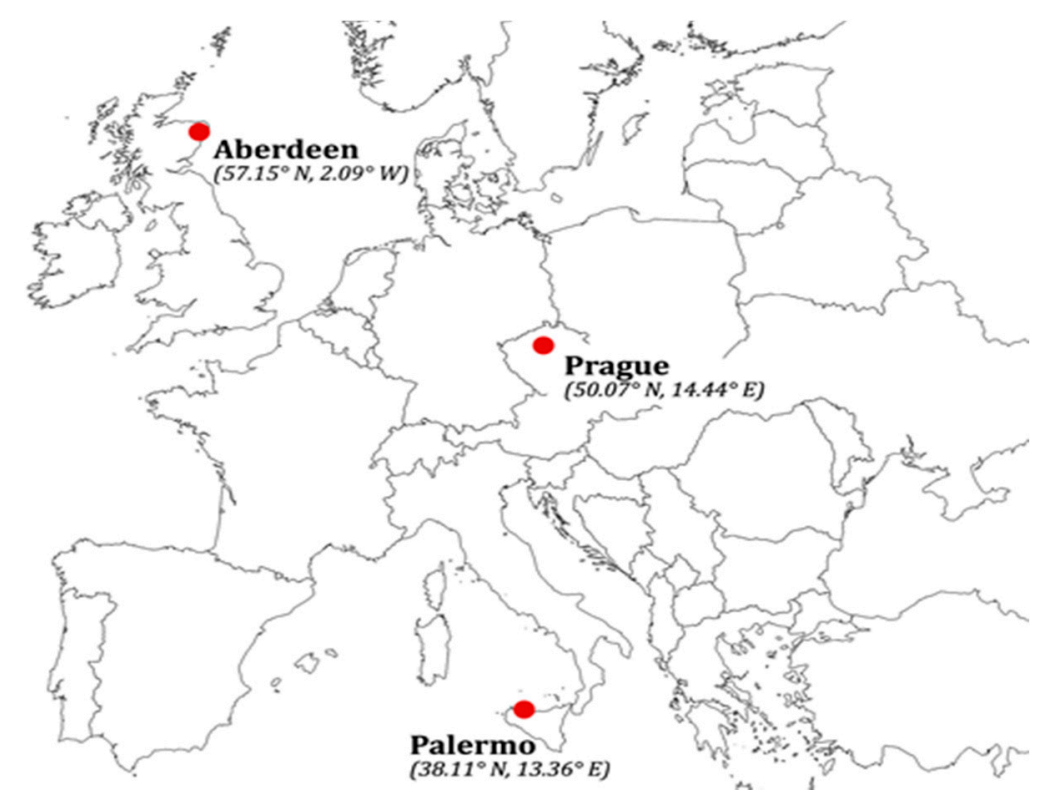

Figure 1. Geographical position and coordinates of the three cities considered. 


\subsection{Weather Data for the EnergyPlus Simulations}

For each city and each time slice, a dynamic simulation was performed with the EnergyPlus software. The input weather data for the simulation related to the present were extracted from the database on the EnergyPlus [30] website, where weather files are available in a specific format (EPW) for more than 2100 locations all over the world. These files provide hourly values of weather variables (e.g., dry bulb and dew point temperatures, relative humidity, atmospheric pressure, wind direction, and intensity) and solar radiation related variables (e.g., radiation, illuminance, sky cover, visibility, etc.) for the typical meteorological year. For simulations relating to 2050 and 2080, the weather data were produced using the climate change tool world weather file generator [37] (e). For each city, this tool produces the weather file typical of the future climate (in particular, for the years 2050 and 2080) starting from the EnergyPlus weather file and using the morphing technique [38]. Used with the EnergyPlus weather file, the input data for the morphing procedure is the HadCM3 model output that corresponds with the A2 emissions scenario. HadCM3 stands for the Hadley center coupled model version 3; it is a general circulation model (GCM) used to performed numerical experiments for "the construction and application of climate change scenarios for climate change impacts assessments" of the Intergovernmental Panel on Climate Change (IPCC). The A2 scenario is one of the emission scenarios constructed by the IPCC about future global production of greenhouse gases and aerosol precursor emissions. CCWorldWeatherGen's users do not have an option to choose between this model and another model for the morphing procedure.

The trend of the current annual temperatures in the three cities is shown in Figure 2.
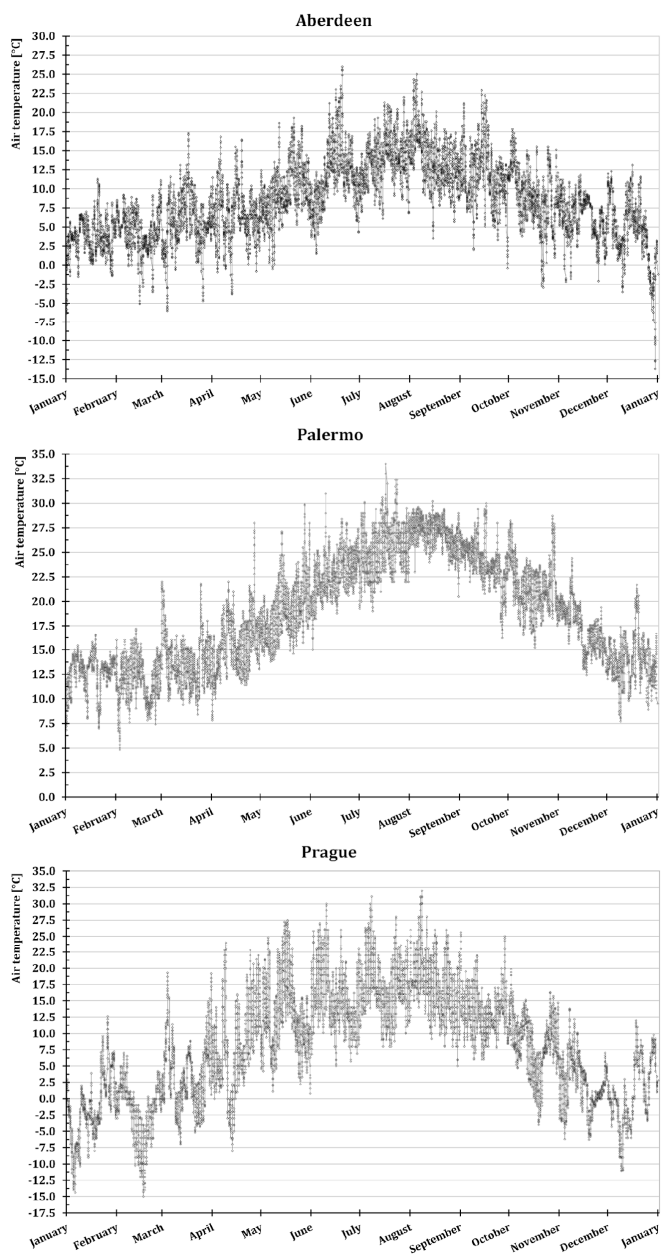

Figure 2. Current annual temperatures in Aberdeen, Palermo, and Prague. 
Using the hourly temperature values provided by the database of EnergyPlus and the CCWorldWeatherGen tool, it is possible to determine the average monthly temperatures for the three cities and three time slices (the present, 2050, and 2080). Figure 3 shows the trends of average monthly temperatures and highlights the average monthly temperature increases in 2050 and 2080 with respect to the current situation.
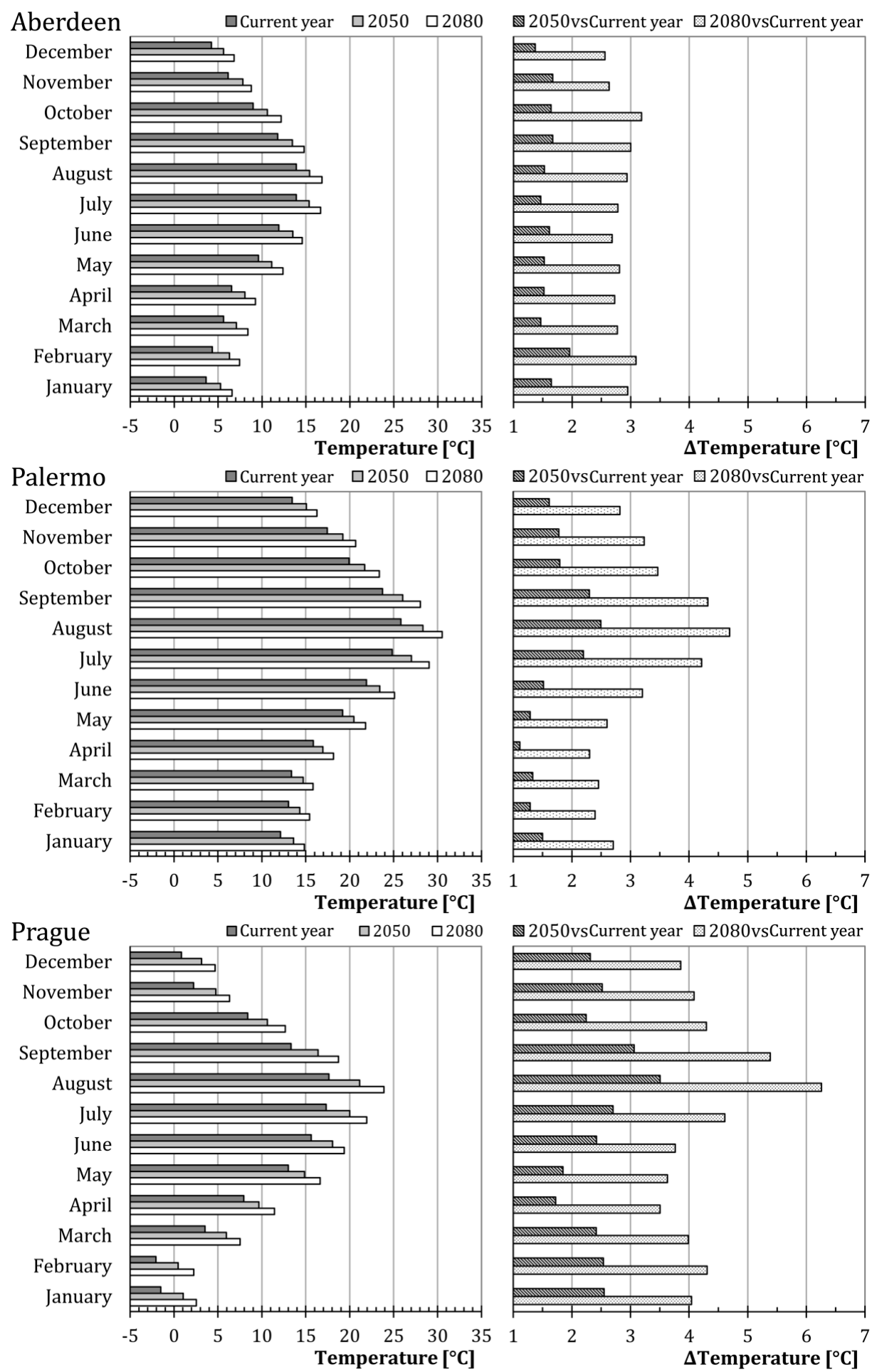

Figure 3. Monthly mean temperatures in Aberdeen, Palermo, and Prague (present, 2050, and 2080, respectively). 
Moreover, the values of heating degree day (HDD) and the cooling degree day (CDD) have been computed for each city and each year. Figure 4 shows the values of HDD and CDD normalized with respect to the current year.

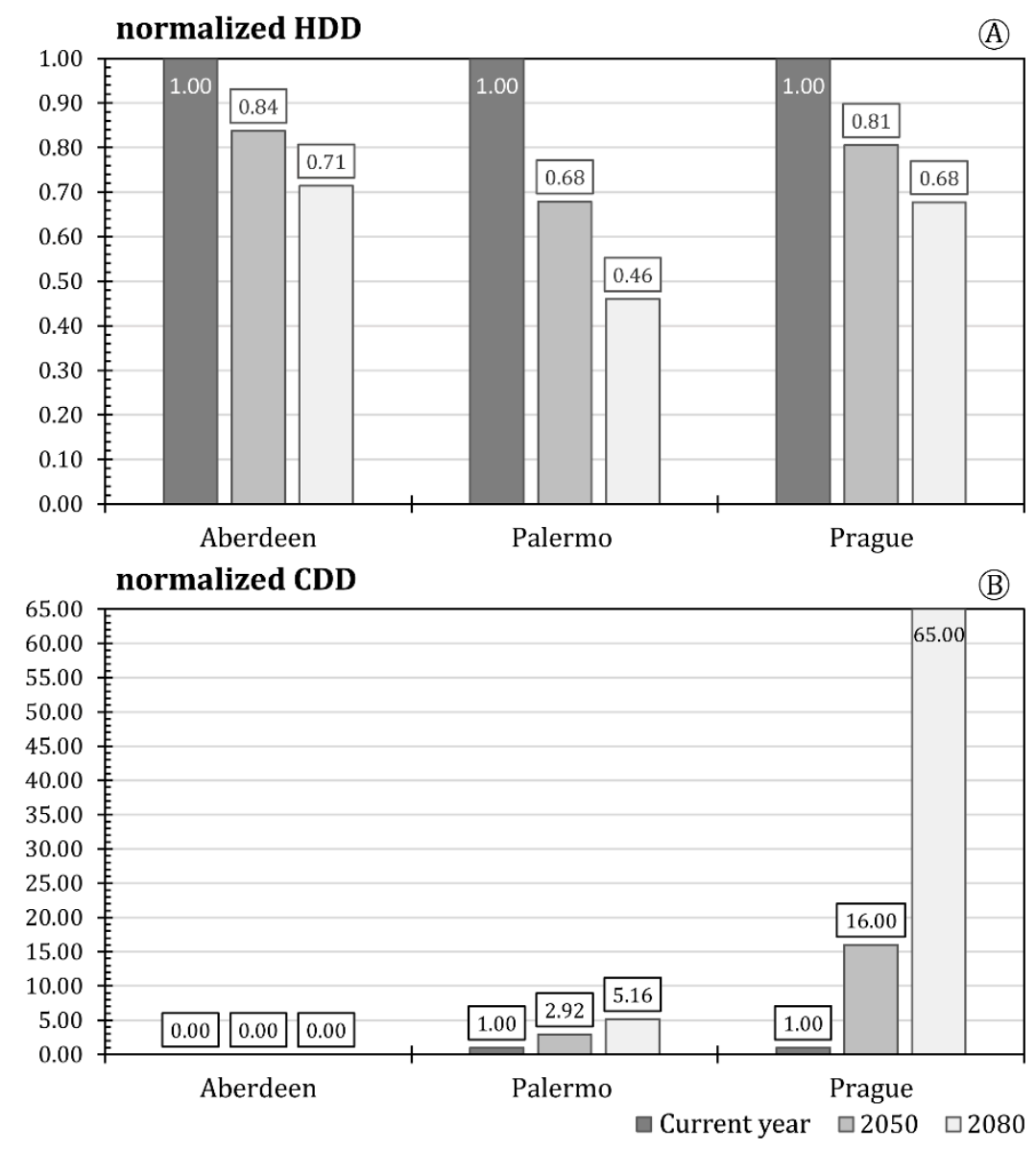

Figure 4. (A) Heating degree day (HDD); (B) cooling degree day (CDD) normalized with respect to the current year for each city.

\subsection{Building Properties}

Figure 5 shows the layout of the building. The "standard floor" represents the story's characterized by nine apartments.

The simulated residential building has a standard structure, with three floors and three apartments per floor. Each apartment is inhabited by four persons and is characterized by a pilotis surface separating the structure from the ground, a flat solar cover, and a south-facing facade with balconies. Thermal transmittance values of the boundary surfaces of the building with respect to the outside are $0.273 \mathrm{~W} \mathrm{~m}^{-2} \mathrm{~K}^{-1}$ for the opaque infill panels and $1.60 \mathrm{~W} \mathrm{~m}^{-2} \mathrm{~K}^{-1}$ for transparent surfaces. Table 1 shows the size and the orientation of these surfaces.

The total internal surface of the building is equal to $1021.44 \mathrm{~m}^{2}$, of which $783.24 \mathrm{~m}^{2}$ are air-conditioned. The internal surface of each floor is equal to $320.4 \mathrm{~m}^{2}$, of which $261.2 \mathrm{~m}^{2}$ are air-conditioned both during the winter (heating) and the summer (cooling) period. The net height of each floor is equal to $2.8 \mathrm{~m}$ for a total internal volume of $3063.6 \mathrm{~m}^{3}$, of which $2192.2 \mathrm{~m}^{3}$ are air-conditioned.

The following features were assumed to characterize the building (designed according to the standards of the early $2000 \mathrm{~s}$ ): (i) heating system to guarantee an indoor temperature of $20^{\circ} \mathrm{C}$ over cold months. The system includes heaters and natural gas condensing boiler with an efficiency of $104.8 \%$ of nominal power; (ii) cooling system to guarantee an indoor temperature of $26^{\circ} \mathrm{C}$ over warm months through a split system with a Coefficient of Performance (C.O.P) equal to 3.1. 


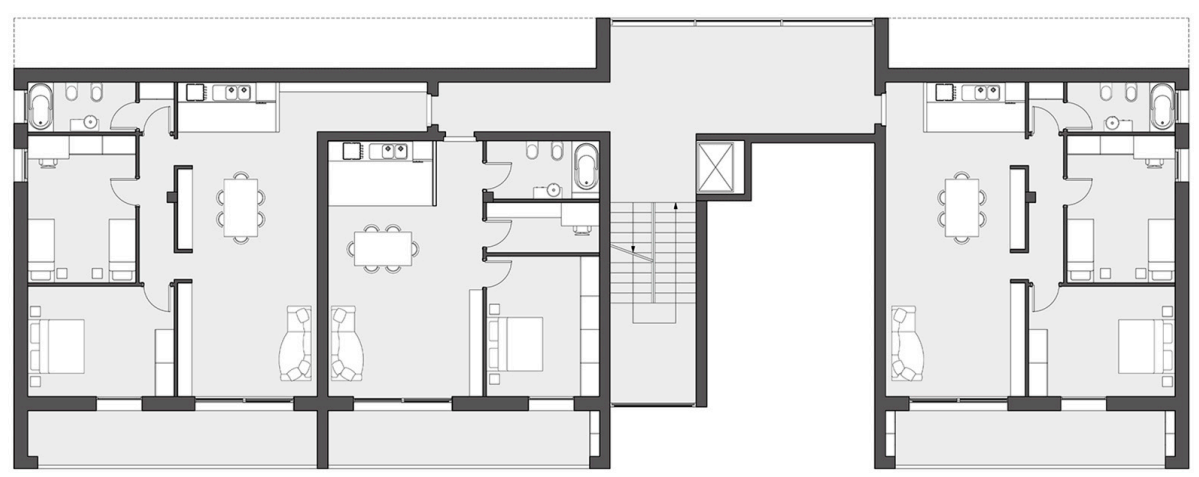

Standard Floor

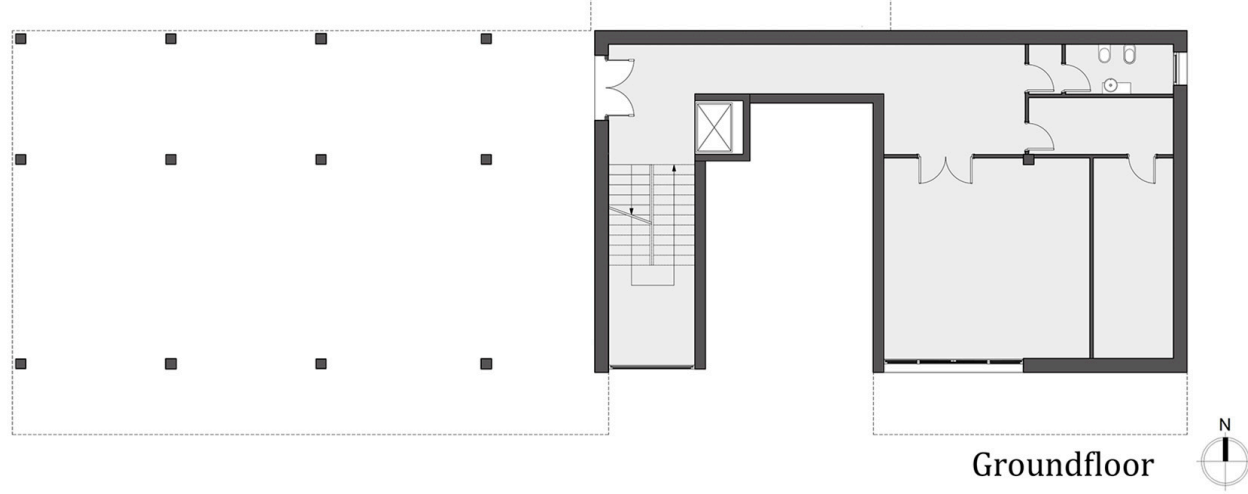

Figure 5. Layouts of the building.

Table 1. Boundary surfaces organized based on their orientation.

\begin{tabular}{ccc}
\hline Type & Orientation & Surface $\left[\mathrm{m}^{2}\right]$ \\
\hline Opaque & North & 258.6 \\
& East & 111.6 \\
& South & 184.5 \\
& West & 81 \\
& Roof & 181.5 \\
& Floor & 181.5 \\
\hline Glass & North & 59.7 \\
& East & 7.6 \\
& South & 112.3 \\
& West & 6.4 \\
\hline
\end{tabular}

Ventilation of inhabited spaces is natural with air changes assumed to equal 0.5 hourly volumes. The internal heating sources for the building are hypothesized according to the regulations and are assumed to equal $38 \mathrm{~W} \cdot \mathrm{m}^{-2}$ (sensible heat gain from people: $70 \mathrm{~W}$ person ${ }^{-1}$; latent heat gain from people $45 \mathrm{~W}$ person $^{-1}$ ). The occupancy schedules are: four persons per apartment, with full occupancy during the night (from $9.00 \mathrm{pm}$ to $8.00 \mathrm{am}$ ). During the daytime, the occupancy of only one person is from 8.00 am to $2.00 \mathrm{pm}$, of two persons from $2.00 \mathrm{pm}$ to $6.00 \mathrm{pm}$, and of three people from $6.00 \mathrm{pm}$ to $9.00 \mathrm{pm}$.

The building was modelled using SketchUp [39] and implemented in EnergyPlus through OpenStudio [40]. EnergyPlus [41,42] is a predictive software developed at the national renewable energy laboratory (NREL) in the US Department of Energy (DOE). Over the last few years, it has become the main software for the energy simulation in buildings. It also gives the possibility to use the files weather of more than 2100 geographical areas all over the world and use customized 
weather files. Thanks to this peculiar feature, starting from the EnergyPlus "current" weather file, it was possible to obtain the weather files for the future (years 2050 and 2080) for the selected cities. To this end, the CCWorldWeatherGen was used. This tool uses the morphing procedure of the typical meteorological year by overlapping the effects of the climate change [43] described by the HadCM3 model output in the four grid points closest to the point examined. Simulations with the EnergyPlus for the three cities examined were performed using the weather file available on the website of EnergyPlus for the "current climate" simulations as input. The output was provided by the CCWorldWeatherGen tool for 2050 and 2080 for the "future climate" simulations.

\section{Results and Discussion}

Different climate conditions in each of the three cities shows how the same building, subjected to different climates, can present completely different energy demands. Thanks to the simulations with EnergyPlus, it was possible to identify the operation hours of the heating and cooling systems. Thus, we could identify the respective operation seasons for the three cities and time slices. The operation seasons can be characterized by certain parameters, such as the number of operation hours, the mean air temperature and standard deviation, the median air temperature, and the extreme air temperatures (minimum air temperature for the winter and maximum temperature for the summer). Values of the mean air temperature and standard deviation, the median air temperature, and the extreme air temperatures are derived from the weather files used as input to EnergyPlus.

These parameters (shown in Tables 2 and 3) allow for the investigation of how the heating and cooling seasons will change in the future (years 2050 and 2080), with the consequences on energy needs described below.

Table 2. Parameters typical of the heating seasons.

\begin{tabular}{|c|c|c|c|c|c|c|}
\hline \multicolumn{2}{|c|}{ Heating Season } & Num Hours [-] & $\mathrm{T}_{\text {mean }}{ }^{1}\left[{ }^{\circ} \mathrm{C}\right]$ & Stand $\operatorname{Dev}^{1}\left[{ }^{\circ} \mathrm{C}\right]$ & $\mathrm{T}_{\min }{ }^{1}\left[{ }^{\circ} \mathrm{C}\right]$ & $\mathrm{T}_{\text {median }}{ }^{1}\left[{ }^{\circ} \mathrm{C}\right]$ \\
\hline \multirow{4}{*}{ Aberdeen } & Now & 5427 & 5.67 & 3.55 & -13.24 & 5.62 \\
\hline & 2050 & 4233 & 6.42 & 3.20 & -11.14 & 6.41 \\
\hline & 2080 & 3646 & 7.27 & 3.14 & -10.24 & 7.29 \\
\hline & Now & 1037 & 11.71 & 2.35 & 5.94 & 11.63 \\
\hline \multirow[t]{2}{*}{ Palermo } & 2050 & 664 & 12.85 & 2.22 & 7.64 & 12.77 \\
\hline & 2080 & 292 & 13.38 & 1.93 & 8.74 & 13.29 \\
\hline \multirow{3}{*}{ Prague } & Now & 4810 & 2.12 & 5.58 & -14.71 & 1.83 \\
\hline & 2050 & 4172 & 3.46 & 4.89 & -11.51 & 3.23 \\
\hline & 2080 & 3719 & 4.43 & 4.61 & -9.61 & 4.23 \\
\hline
\end{tabular}

${ }^{1}$ Mean air temperature $\left(\mathrm{T}_{\text {mean }}\right)$ and standard deviation (Stand dev), median air temperature $\left(\mathrm{T}_{\text {median }}\right)$, and $\mathrm{T}_{\min }$ are derived from the weather files used as input to EnergyPlus.

Table 3. Parameters typical of the cooling seasons.

\begin{tabular}{|c|c|c|c|c|c|c|}
\hline \multicolumn{2}{|c|}{ Cooling Season } & \multirow{2}{*}{$\begin{array}{c}\text { Num Hours [-] } \\
2\end{array}$} & \multirow{2}{*}{$\begin{array}{c}\mathrm{T}_{\text {mean }}{ }^{1}\left[{ }^{\circ} \mathrm{C}\right] \\
24.45\end{array}$} & \multirow{2}{*}{$\begin{array}{c}\text { Stand } \operatorname{Dev}^{1}\left[{ }^{\circ} \mathrm{C}\right] \\
0.3\end{array}$} & \multirow{2}{*}{$\begin{array}{c}\mathrm{T}_{\max }{ }^{1}\left[{ }^{\circ} \mathrm{C}\right] \\
24.67\end{array}$} & \multirow{2}{*}{$\frac{\mathrm{T}_{\text {median }}{ }^{1}\left[{ }^{\circ} \mathrm{C}\right]}{24.45}$} \\
\hline & Now & & & & & \\
\hline \multirow[t]{3}{*}{ Aberdeen } & 2050 & 40 & 21.34 & 2.13 & 25.97 & 21.12 \\
\hline & 2080 & 109 & 21.14 & 2.37 & 27.31 & 20.88 \\
\hline & Now & 1289 & 24.03 & 2.97 & 34.27 & 23.99 \\
\hline \multirow[t]{3}{*}{ Palermo } & 2050 & 1978 & 26.42 & 3.18 & 36.77 & 26.77 \\
\hline & 2080 & 2668 & 27.96 & 3.4 & 38.87 & 28.46 \\
\hline & Now & 117 & 23.92 & 3 & 30.83 & 23.58 \\
\hline \multirow[t]{2}{*}{ Prague } & 2050 & 552 & 23.37 & 4.42 & 36.88 & 22.71 \\
\hline & 2080 & 859 & 24.92 & 5.13 & 41.04 & 24.38 \\
\hline
\end{tabular}

${ }^{1}$ Mean air temperature $\left(\mathrm{T}_{\text {mean }}\right)$ and standard deviation (Stand dev), median air temperature $\left(\mathrm{T}_{\text {median }}\right)$, and $\mathrm{T}_{\max }$ are derived from the weather files used as input to EnergyPlus.

For both the heating and cooling systems, this article examines: (i) peak power (annual) based on the future climate change, which is an interesting factor for technicians called to plan systems and to evaluate the capacities of installed systems with regard to climate change; (ii) median power 
(annual) when the system is active, in order to fulfill the climatization demand to know the time modulation of the installed power; (iii) energy consumptions (monthly and annual) based on future climate conditions, to provide more precise predictions about future energy consumptions in different climatic areas.

The monthly values of the energy needs in the analyzed building and the corresponding increases in future scenarios were computed based on the conditions described in Figure 3 and are summarized in Figure 5.

Results in Figure 6 indicate a decreasing demand for heating, especially in the Mediterranean area (where the energy demand for heating is already very low compared to the cities located further north). On the other hand, it also demonstrates a considerable increase in needs for summer cooling. Instead, in Aberdeen, there is currently no need for summer air conditioning and therefore there is no need to install fitting systems. In the future, however, this need will arise during the central summer months. These conclusions also apply to Prague, with more pronounced trends.

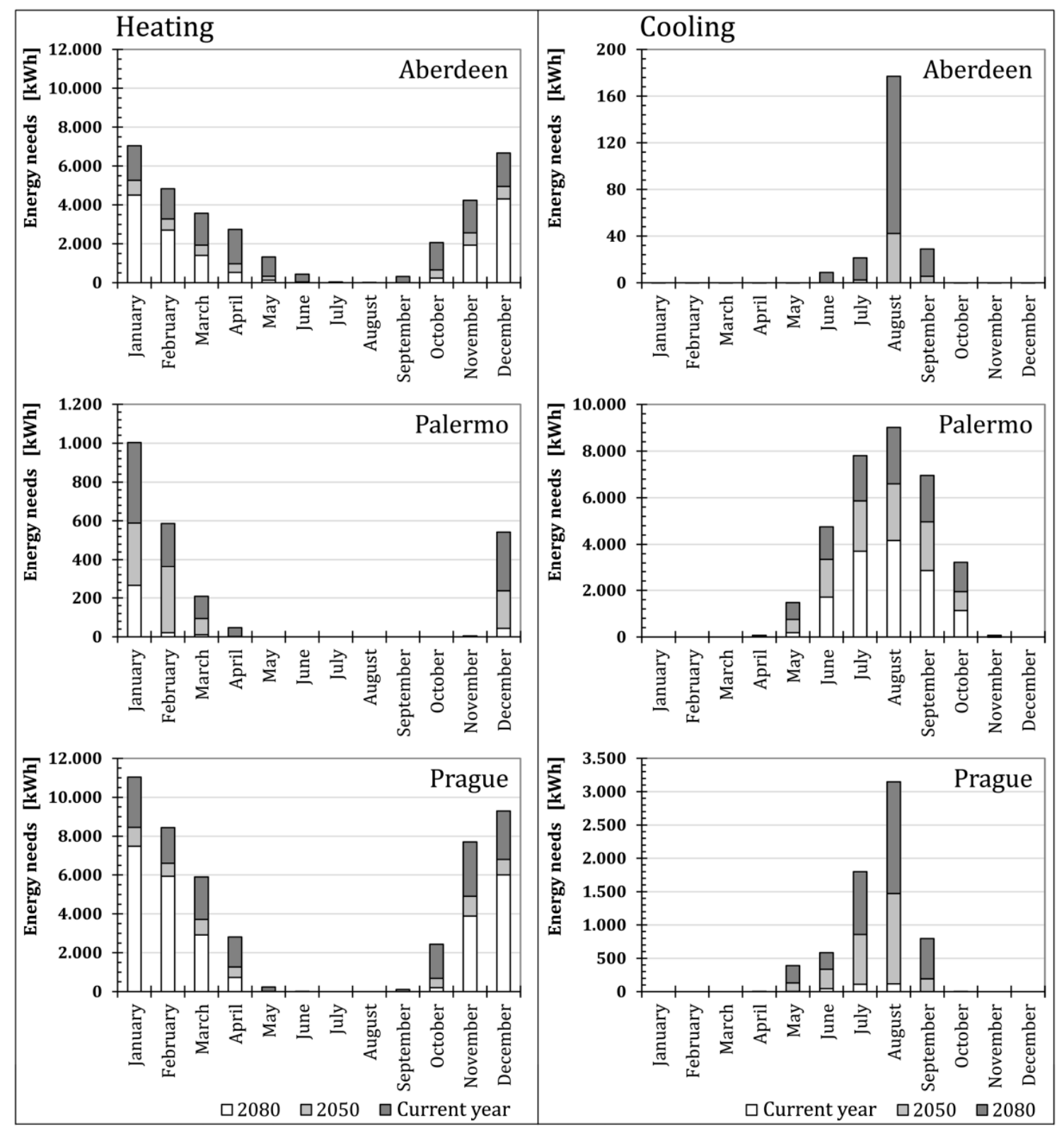

Figure 6. Monthly heating and cooling energy needs $[\mathrm{kWh}]$ in the building examined based for the cities and scenarios considered. 
Figure 7 shows the annual values of peak power (Figure 7a), median power (Figure 7b), and energy needs (Figure 7c) for the cities analyzed in the different time scenarios.
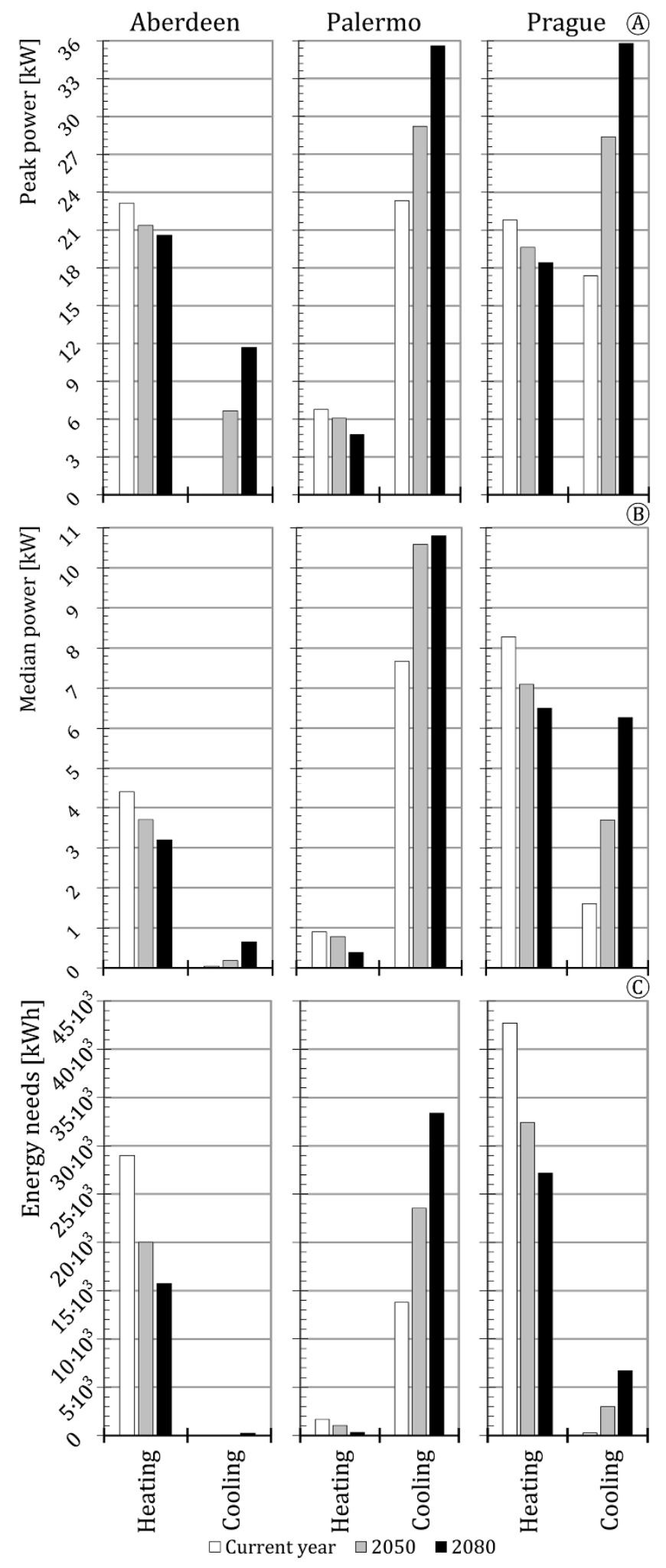

Figure 7. Annual values of: (A) peak power [kW]; (B) median power [kW]; (C) energy demand for heating and cooling $[\mathrm{kWh}]$ the building examined based on the city and scenario. 
In terms of annual quantities, the peak power (Figure 7a) that has to be fulfilled by the systems can define the potentiality of the system (of the boiler for the cooling and chiller for the heating). These necessities decrease over the winter. Thus, a boiler sized for the current demand will result in oversized boilers in the future. During the summer, the situation is even more difficult. The cooling system peak power presents a general increase, which makes the present systems under-dimensioned and unable to guarantee the thermo-hygrometric comfort during the heavy summer days.

As Figure 7a shows, the decrease in the heating peak power corresponds to a higher percentage increase of the cooling peak energy demand. However, if the focus shifts onto the values of the median hourly power (Figure $7 \mathrm{~b}$ ) during the hours when heating or cooling systems are working, it is possible to notice that the power demand has the same trend of the peak power. It is obvious that such information represents a prediction that the future energy demand will decrease over winter and increase in the summer.

Prague is characterized by the lowest winter temperature values and at the same time by the highest average temperature increase, which in 2080 will be more than double the current one. The trend of the graphs concerning the energy consumptions (Figure 7c) proves that the heating energy in Prague currently represents the highest energy demands. This stresses the extent to which the current winter climate is rigid. An opposite situation characterizes Palermo, a typical Mediterranean city, where during the winter the energy demand is very low. Aberdeen, with its North Atlantic climate, shows a halfway situation between Prague and Palermo.

Shifting the attention onto future projections, it can be noticed how the heating demand in Palermo approaches zero. In a similar way, winter energy consumption decreases in the other two cities. Although the average temperature in Aberdeen increases less than Prague, the variation in energy needs is similar. Even in 2080, Prague will remain the city with the highest energy requirement, which will be similar to the current one in Aberdeen. Overall, global warming in Europe will lead to mild winter with reduced demand for heating.

Regarding the energy demand for cooling systems (Figure 7c), currently Aberdeen is negligible (two operation hours) and the number of hours of cooling will increase 20 times in 2050 and 50 times in 2080. In 2080, Prague will increase by about 7 times and in Palermo by about 2 times. In Aberdeen, the cooling consumptions will remain negligible, while in Prague they will increase (even though they do not present high values). On the other hand, in Palermo, the energy consumptions over the summer will increase even more up to double in 2080.

In the future, the decreasing consumption of energy resources for cooling will be largely outweighed by the growing needs for electric energy for cooling.

This shows how the climate change will make the geographical areas in southern Europe extremely warm; maintaining comfort conditions inside buildings will require higher amount of energy.

In 2050 and 2080 energy consumption for heating and cooling will increase in percentage as shown in Table 4.

Table 4. Energy demand variations compared to the current year.

\begin{tabular}{cccc}
\hline City & Year & Heating & Cooling \\
\hline \multirow{2}{*}{ Aberdeen } & 2050 & $-31 \%$ & $55,014 \%$ \\
& 2080 & $-46 \%$ & $259,129 \%$ \\
\hline \multirow{2}{*}{ Palermo } & 2050 & $-37 \%$ & $71 \%$ \\
& 2080 & $-80 \%$ & $142 \%$ \\
\hline \multirow{2}{*}{ Prague } & 2050 & $-24 \%$ & $973 \%$ \\
& 2080 & $-36 \%$ & $2316 \%$ \\
\hline
\end{tabular}

The high percentage values of Aberdeen and Prague are due to the fact that the current values are very small. Figure $7 \mathrm{c}$ shows the change in time of the energy consumption for cooling and heating in the studied building. 


\section{Conclusions}

In the near future, climate change will affect the heating and cooling energy demands in residential buildings. In Europe, the climate will undergo a general warming, to different degrees, for different geographical areas.

The change in the global climate will lead to mild winters all over Europe. Such conditions will be advantageous in terms of energy for northern regions (westward, on the Atlantic side, and eastward in the hinterland). Future climate conditions will lead to remarkable energy savings for heating in the geographical areas currently characterized by rigid climates. However, over the summer, European continental countries will experience an increase in cooling energy demands. On the other hand, cities located in southern Europe will experience long and frequent periods of intense summer heat. These phenomena, which today are considered uncommon, will become more recurrent. In these situations, keeping comfort temperatures inside buildings will be an onerous task. Moreover, current cooling systems will become under-dimensioned and it will be necessary to re-plan them in order to fulfill the peak power demand.

This article focused on the future climate trend and its effect on the energy consumptions required to guarantee thermo-hygrometric comfort conditions inside residential buildings. It is assumed that the analyzed building maintains its characteristics (both of its envelope and its installations) over time in order to analyze the future trends of energy consumption due to climate change. Even if authors are aware of thermo-physical characteristics, it will change in the future, and this investigation of the resilience of the simulated building to the external climatic conditions required this assumption.

Simulations of the energy demand for heating and cooling a hypothetical building dating back to the early 2000s have been performed through the dynamical software EnergyPlus, which hypothesizes that the building is located in three European cities characterized by different climatic types. The time step considered for the future climatic scenario is thirty years. The simulation concerns the present, the year 2050, and the year 2080.

Results presented here highlighted the impact of climate change on energy performance and the resilience of the same building, which had different importance for the three different cities. This underlines the need to examine the exposure the risk associated with climate change for European cities as a function of their geographical location. Therefore, this article should be considered as the first step towards a more extended research across Europe, considering the influence of the latitude and the Köppen-Geiger climate class. This will allow us to understand the influence of different climatic conditions (and mutations due to global warming in the next decades) on energy consumptions on a European scale.

It is important to focus and examine the possible energy behavior of buildings exposed to future weather conditions through data based on studied climatic region. It is also important to understand the future effects on the functioning of systems dimensioned according to the outdoor temperatures provided by the historical data. Moreover, this type of analysis can be useful to perform projections about the future global energy demand, taking into consideration both the energy optimization effort in the residential sector and the future evolution of the demand of the set building envelope/system.

Future development of this work will also include an in-depth analysis of the evolution of energy consumption in a standard building in terms of number of operation hours, peak power, annual and hourly average energy consumption, and standard deviation of energy consumption. Furthermore, the annual amount of carbon dioxide produced will be quantified for the three time slices. Indeed, the type of energy required must be taken into consideration. If the energy demand for heating the residential buildings can be fulfilled through the combustion of hydrocarbon (as the methane in this case), the energy demand for the cooling is strongly linked to electricity. This will lead to higher costs since electricity is an energy vector that is usually more expensive than other energy sources (especially in the future where the demand of electrical energy will increase to fulfill the demand of the new market of electric cars). Furthermore, the electric power installed and distributed to the national network will be higher in order to fulfill the increasing peaks in the electric energy demand for 
air-conditioning systems. However, in the future, the demand of electricity could be satisfied through renewable energies and this, together with an elevated reduction of non-renewable energies demand for heating, could have a reduced impact on the environment.

Author Contributions: All the authors have contributed equally to the realization of this research.

Funding: Ferdinando Salata received for this research a grant on the "Progetti di Ricerca—Progetti Medi 2018" from Sapienza University of Rome.

Acknowledgments: Iacopo Golasi thanks the Sapienza University for the contribution provided with its research grant entitled "Activities related to the design and construction of new high-efficiency plant systems for the Sapienza building stock-New external artistic lighting for prestigious buildings of the University".

Conflicts of Interest: The authors declare no conflict of interest.

\section{References}

1. Ürge-Vorsatz, D.; Eyre, N.; Graham, P.; Harvey, D.; Hertwich, E.; Jiang, Y.; Kornevall, C.; Majumdar, M.; McMahon, J.E.; Mirasgedis, S.; et al. Energy End-Use: Buildings. In Global Energy Assessment-Toward a Sustainable Future; Cambridge University Press: Cambridge, UK, 2012; pp. 649-760.

2. Cao, X.; Dai, X.; Liu, J. Building energy-consumption status worldwide and the state-of-the-art technologies for zero-energy buildings during the past decade. Energy Build. 2016, 128, 198-213. [CrossRef]

3. McKinsey Global Institute. Global Energy Perspective 2019: Reference Case; McKinsey Global Institute: Washington, DC, USA, 2019.

4. Salata, F.; Golasi, I.; Domestico, U.; Banditelli, M.; Lo Basso, G.; Nastasi, B.; de Lieto Vollaro, A. Heading towards the nZEB through CHP + HP systems. A comparison between retrofit solutions able to increase the energy performance for the heating and domestic hot water production in residential buildings. Energy Convers. Manag. 2017, 138, 61-76. [CrossRef]

5. Ciancio, V.; Salata, F.; Falasca, S.; Curci, G.; Golasi, I.; de Wilde, P. Future energy demands of European buildings in the framework of climate change: A scoping study. In CEUR Workshop Proceedings; Geyer, P., De Troyer, F., Allacker, K., Schevenels, M.P.P., Eds.; CEUR-WS: Leuven, Belgium, 2019; p. 2394.

6. Dudley, B. BP Energy Outlook 2019 Edition; BP p.l.c.: London, UK, 2019; p. 73.

7. Zhao, X.; Zuo, J.; Wu, G.; Huang, C. A bibliometric review of green building research 2000-2016. Archit. Sci. Rev. 2019, 62, 74-88. [CrossRef]

8. Burattini, C.; Nardecchia, F.; Bisegna, F.; Cellucci, L.; Gugliermetti, F.; Vollaro, A.; Salata, F.; Golasi, I. Methodological Approach to the Energy Analysis of Unconstrained Historical Buildings. Sustainability 2015, 7, 10428-10444. [CrossRef]

9. Sadineni, S.B.; Madala, S.; Boehm, R.F. Passive building energy savings: A review of building envelope components. Renew. Sustain. Energy Rev. 2011, 15, 3617-3631. [CrossRef]

10. Falasca, S.; Ciancio, V.; Salata, F.; Golasi, I.; Rosso, F.; Curci, G. High albedo materials to counteract heat waves in cities: An assessment of meteorology, buildings energy needs and pedestrian thermal comfort. Build. Environ. 2019, 163, 106242. [CrossRef]

11. Lo Basso, G.; Nastasi, B.; Salata, F.; Golasi, I. Energy retrofitting of residential buildings-How to couple Combined Heat and Power (CHP) and Heat Pump (HP) for thermal management and off-design operation. Energy Build. 2017, 151, 293-305. [CrossRef]

12. Chua, K.J.; Chou, S.K.; Yang, W.M.; Yan, J. Achieving better energy-efficient air conditioning - A review of technologies and strategies. Appl. Energy 2013, 104, 87-104. [CrossRef]

13. Allouhi, A.; El Fouih, Y.; Kousksou, T.; Jamil, A.; Zeraouli, Y.; Mourad, Y. Energy consumption and efficiency in buildings: Current status and future trends. J. Clean. Prod. 2015, 109, 118-130. [CrossRef]

14. Andrić, I.; Pina, A.; Ferrão, P.; Fournier, J.; Lacarrière, B.; Le Corre, O. The impact of climate change on building heat demand in different climate types. Energy Build. 2017, 149, 225-234. [CrossRef]

15. AR5 Climate Change 2014: Impacts, Adaptation, and Vulnerability-IPCC. Available online: https://www. ipcc.ch/report/ar5/wg2/ (accessed on 8 February 2019).

16. Coakley, J.A.; Hansen, J.E.; Hofmann, D.J. Anthropogenic Perturbation of Tropospheric. Science 1992, $255,423-430$. 
17. Kershaw, T.; Eames, M.; Coley, D. Assessing the risk of climate change for buildings: A comparison between multi-year and probabilistic reference year simulations. Build. Environ. 2011, 46, 1303-1308. [CrossRef]

18. Moazami, A.; Nik, V.M.; Carlucci, S.; Geving, S. Impacts of future weather data typology on building energy performance-Investigating long-term patterns of climate change and extreme weather conditions. Appl. Energy 2019, 238, 696-720. [CrossRef]

19. Guan, L. Preparation of future weather data to study the impact of climate change on buildings. Build. Environ. 2009, 44, 793-800. [CrossRef]

20. Ciancio, V.; Falasca, S.; Golasi, I.; Curci, G.; Coppi, M.; Salata, F. Influence of input climatic data on simulations of annual energy needs of a building: EnergyPlus and WRF modeling for a case study in Rome (Italy). Energies 2018, 11, 2835. [CrossRef]

21. Shen, P. Impacts of climate change on US building energy use by using downscaled hourly future weather data. Energy Build. 2017, 134, 61-70. [CrossRef]

22. Sanders, C.H.; Phillipson, M.C. UK adaptation strategy and technical measures: The impacts of climate change on buildings. Build. Res. Inf. 2003, 31, 210-221. [CrossRef]

23. Camilleri, M.; Jaques, R.; Isaacs, N. Impacts of climate change on building performance in New Zealand. Build. Res. Inf. 2001, 29, 440-450. [CrossRef]

24. Li, M.; Guo, J.; Tian, Z.; Shi, J.; Xiong, M.; Xiang, C. Future climate change and building energy demand in Tianjin, China. Build. Serv. Eng. Res. Technol. 2014, 35, 362-375. [CrossRef]

25. Dirks, J.A.; Gorrissen, W.J.; Hathaway, J.H.; Skorski, D.C.; Scott, M.J.; Pulsipher, T.C.; Huang, M.; Liu, Y.; Rice, J.S. Impacts of climate change on energy consumption and peak demand in buildings: A detailed regional approach. Energy 2015, 79, 20-32. [CrossRef]

26. Invidiata, A.; Ghisi, E. Impact of climate change on heating and cooling energy demand in houses in Brazil. Energy Build. 2016, 130, 20-32. [CrossRef]

27. Chan, A.L.S. Developing future hourly weather files for studying the impact of climate change on building energy performance in Hong Kong. Energy Build. 2011, 43, 2860-2868. [CrossRef]

28. Kalvelage, K.; Passe, U.; Rabideau, S.; Takle, E.S. Changing climate: The effects on energy demand and human comfort. Energy Build. 2014, 76, 373-380. [CrossRef]

29. Jylhä, K.; Jokisalo, J.; Ruosteenoja, K.; Pilli-sihvola, K.; Kalamees, T.; Seitola, T.; Mäkelä, H.M.; Hyvönen, R.; Laapas, M. Energy demand for the heating and cooling of residential houses in Finland in a changing climate. Energy Build. 2015, 99, 104-116. [CrossRef]

30. Barbosa, R.; Vicente, R.; Santos, R. Climate change and thermal comfort in Southern Europe housing: A case study from Lisbon. Build. Environ. 2015, 92, 440-451. [CrossRef]

31. Nik, V.M.; Sasic Kalagasidis, A. Impact study of the climate change on the energy performance of the building stock in Stockholm considering four climate uncertainties. Build. Environ. 2013, 60, 291-304. [CrossRef]

32. Wan KK, W.; Li DH, W.; Pan, W.; Lam, J.C. Impact of climate change on building energy use in different climate zones and mitigation and adaptation implications. Appl. Energy 2012, 97, 274-282. [CrossRef]

33. Wang, X.; Chen, D.; Ren, Z. Assessment of climate change impact on residential building heating and cooling energy requirement in Australia. Build. Environ. 2010, 45, 1663-1682. [CrossRef]

34. Ouedraogo, B.I.; Levermore, G.J.; Parkinson, J.B. Future energy demand for public buildings in the context of climate change for Burkina Faso. Build. Environ. 2012, 49, 270-282. [CrossRef]

35. Peel, M.C.; Finlayson, B.L.; Mcmahon, T.A. Updated world map of the Koppen-Geiger climate classification. Hydrol. Earth Syst. Sci. Discuss. 2007, 4, 439-473. [CrossRef]

36. Kottek, M.; Grieser, J.; Beck, C.; Rudolf, B.; Rubel, F. World map of the Köppen-Geiger climate classification updated. Meteorol. Z. 2006, 15, 259-263. [CrossRef]

37. Jentsch, M.F.; Bahaj, A.S.; James, P.A. Climate change future proofing of buildings—Generation and assessment of building simulation weather files. Energy Build. 2008, 40, 2148-2168. [CrossRef]

38. Mavrogianni, A.; Davies, M.; Batty, M.; Belcher, S.E.; Bohnenstengel, S.I.; Carruthers, D.; Chalabi, Z.; Croxford, B.; Demanuele, C.; Evans, S.; et al. The comfort, energy and health implications of London's urban heat island. Build. Serv. Eng. Res. Technol. 2011, 32, 35-52. [CrossRef]

39. Trimble Inc. SketchUp. Available online: https://www.sketchup.com/it (accessed on 4 August 2019).

40. National Renewable Energy Laboratory. OpenStudio. Available online: https://www.openstudio.net/ (accessed on 4 August 2019). 
41. Crawley, D.B.; Hand, J.W.; Kummert, M.; Griffith, B.T. Contrasting the capabilities of building energy performance simulation programs. Build. Environ. 2008, 43, 661-673. [CrossRef]

42. Deru, M.; Field, K.; Studer, D.; Benne, K.; Griffith, B.; Torcellini, P.; Liu, B.; Halverson, M.; Winiarski, D.; Rosenberg, M.; et al. US Department of Energy Commercial Reference Building Models of the National Building Stock; National Renewable Energy Laboratory: Golden, CO, USA, 2011.

43. Jentsch, M.F.; Chang, C.K.; James, P.A.; Bahaj, A.S.; Yau, Y.H. Development of climate change adapted weather files for building performance simulation. In Proceedings of the 3rd International Conference on Sustainable Energy and Environment (SSE 2009), Bangkok, Thailand, 18-23 May 2009; pp. 1-6.

(C) 2019 by the authors. Licensee MDPI, Basel, Switzerland. This article is an open access article distributed under the terms and conditions of the Creative Commons Attribution (CC BY) license (http://creativecommons.org/licenses/by/4.0/). 